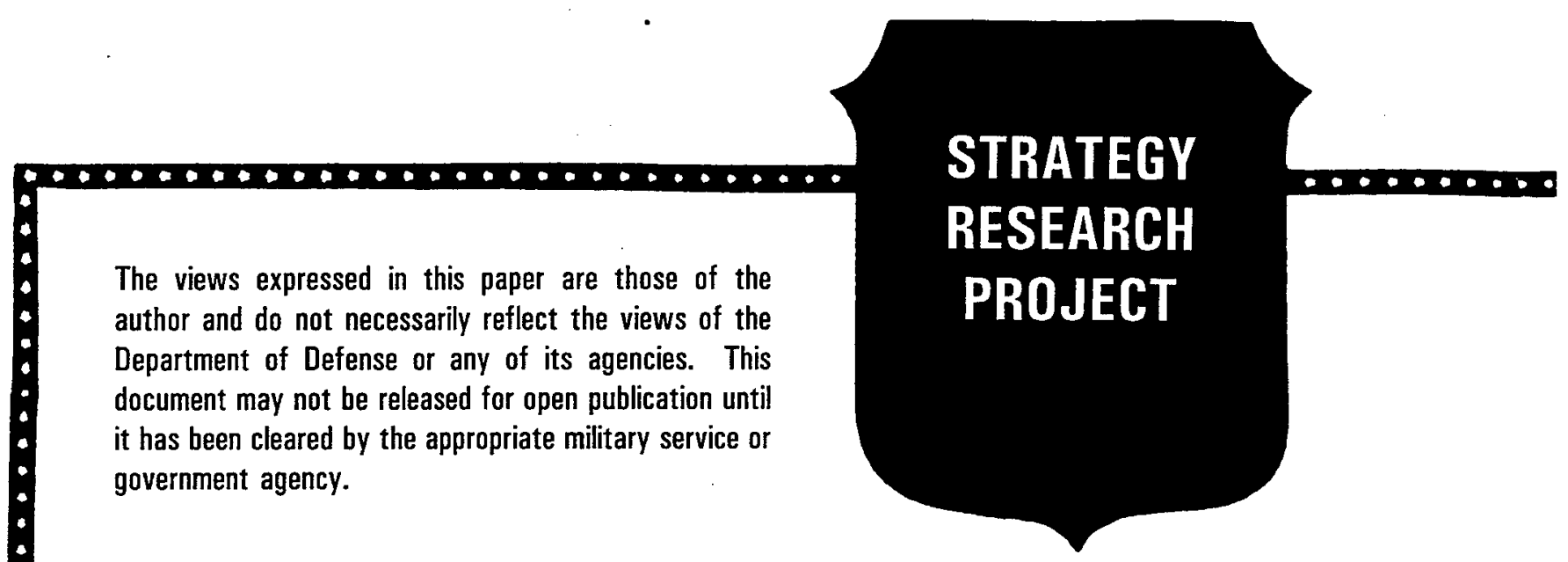

\title{
IMPLICATIONS FOR A FUTURE NON-LINEAR DOCTRINE: OPERATIONS OF GERMAN ARMY GROUP SOUTH (WINTER, 1942-1943)
}

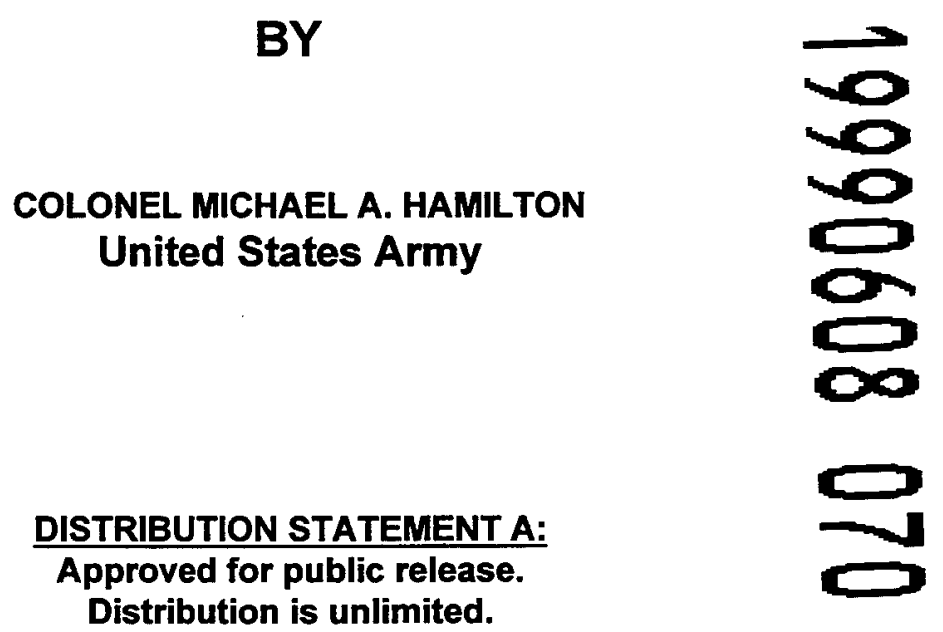

USAWC CLASS OF 1999

U.S. ARMY WAR COLLEGE, CARLISLE BARRACKS, PA 17013-5050 
IMPLICATIONS FOR A FUTURE NON-LINEAR DOCTRINE:

OPERATIONS OF GERMAN ARMY GROUP SOUTH (WINTER, 1942-1943)

\author{
by
}

COL Michael A. Hamilton

United States Army

\title{
Dr. Douglas V. Johnson II \\ Project Advisor
}

The views expressed in this academic research paper are those of the author and do not necessarily reflect the official policy or position of the U.S. Government, the Department of Defense, or any of its agencies.

$$
\begin{aligned}
& \text { DISTRIBUTION STATEMENT A: } \\
& \text { Approved for public release. } \\
& \text { Distribution is unlimited. }
\end{aligned}
$$




\section{ABSTRACT}

AUTHOR: Michael A. Hamilton, COL, U.S. Army

TITLE: Implications for a Future Non-linear Doctrine - Operations of German Army Group South (Winter, 1942-1943)

FORMAT: Strategy Research Project

DATE: 23 March 1999 PAGES: 42 CLASSIFICATION: Unclassified

To not repeat the lessons of the past, the Army strives to provide relevant historical underpinnings to new concepts, processes and doctrine. It is difficult to find an example of a large mechanized force successfully using non-linear tactics in a modern context. However, the Germans in Russia, by circumstance rather than choice, were often forced to deal with the expanses of Russia, and insufficient forces, by means we could characterize as nonlinear. Perhaps the best example is the series of operations from December 1942 through March 1943. In this campaign, the Germans planned and executed a brilliantly conceived defense and counter-stroke that destroyed several Soviet armies and stabilized the southern front. A review of this operation provides direct lessons learned and inferences as to the necessary political and military conditions making Army non-linear and deployment concepts feasible for tomorrow's conflicts. The campaign's conduct highlights lessons and implications in six major areas that are explored:

- Reliance on Allies and Their Warfighting Capabilities

- A Required Transformation in Civil-Military Relations

- Political and Media Impacts to Operations - Shaping the Media Environment

- Mismatch between the American Way of War and Non-Linear Concepts

- Mismatch in Army and Air Force Concepts and Doctrine

- A Decline in "Rear Area" Security 


\section{TABLE OF CONTENTS}

ABSTRACT_

TABLE OF CONTENTS __ $v$

LIST OF ILLUSTRATIONS__ vii

INTRODUCTION _L 1

THE FUTURE SETTING AND ITS ASSUMPTIONS___ 2

OUTLINE OF THE NEW DOCTRINE___ 3

The Setting

The Soviets Press Their Advantage __ 7

The German Counterstroke Takes Form __ 9

Political Intervention Endangers the Campaign___ 12

The German Counterstroke 14

LESSONS AND IMPLICATIONS FOR NEW U.S. CONCEPTS __ 15

Reliance on Allies and Their Warfighting Capabilities _ 15

A Required Transformation in Civil-Military Relations __ 17

Political and Media Impacts to Operations - Shaping the Media Environment __ 19

Mismatch between the American Way of War and Non-Linear Concepts___ 21

Mismatch in Army and Air Force Concepts and Doctrine __ 23

A Decline in "Rear Area" Security __ 24

A CALL TO ACTION__ 26

CONCLUSION _ 28

ENDNOTES _ 31

BIBLIOGRAPHY_ 33 


\section{LIST OF ILLUSTRATIONS}

Figure 1: Army Group South Area of Operations..............................................

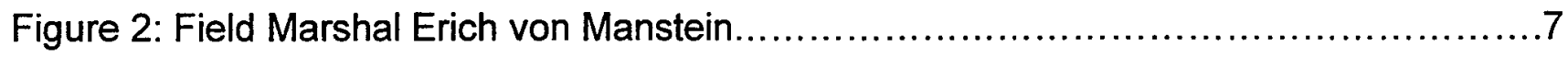

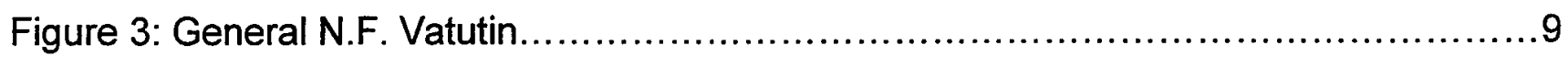

Figure 4: Generaloberst Hermann Hoth...................................................... 
Companion, it is your own doing, for knightly courage used with prudence is one thing and folly is another, and tempered judgement is more to be valued than the rashness of arrogance.

— Oliver to Roland, The Song of Roland, 1096 AD

\section{INTRODUCTION}

Since the early nineties the Army has struggled to understand the doctrinal opportunities and problems associated with the security environment of the next century. This period of changing international relationships and social tolerances, combined with new or greatly improved technologies, will affect how the Army fights. To date, this vision has included the development of "Force XXI" concepts seen as being valid until 2015 (the nearand mid-term), and by Army After Next (ANN) concepts for after 2015 (the far-term). Both concepts present a battlefield both enabled and driven by greatly improved friendly and threat situational awareness, command and control, targeting, and a smaller U.S. fighting force. The concepts depict a battlefield where forces are deployed and employed more quickly and the security blanket of "friendly lines" has been lost and are replaced by dispersed forces that only come together for decisive combat - the non-linear (or empty) battlefield.

To more fully understand new concepts and their implications, the Army has found it useful to look at analogous examples from the past - situations providing lessons learned and inferences for the future battlefield. For non-linear warfare, it's difficult to find an example of a large land force successfully using non-linear tactics in a modern context. However, the German experience on the Eastern Front of World War II, a conflict often ignored, provides snapshots of non-linear operations in certain periods. The Germans in Russia, by circumstance rather than by choice, were often forced to deal with Russia's expanse and its insufficient forces by means we could easily characterize as non-linear. 
Perhaps the best example is the series of operations from November 1942 through March 1943, following the disaster at Stalingrad. Here, Field Marshal Erich von Manstein planned and supervised the execution of a brilliantly conceived defense and counter-stroke that destroyed several Soviet armies, stabilized the southern wing, and provided the stage for the German summer offensive of 1943 - a campaign often referred to as "the miracle of the Donets". A review of this seven-month period and the foundations of German success can provide us direct lessons learned and inferences as to the necessary conditions (environment) making non-linear operations and our new deployment concepts a viable option for tomorrow's operations.

This study will provide a short review of the future environment and the concepts presently envisioned in current Army writings; it will outline the German campaign; and then examine lessons learned and inferred for our future environment. The study will show that, when combined with the employment concepts envisioned for Force XXI and Army After Next, non-linearity is a viable operational concept, but that there are many issues in the political and military domain that must be addressed if the concepts are to be successful.

\section{THE FUTURE SETTING AND ITS ASSUMPTIONS}

Predicting the environment to the year 2025 with any precision is obviously impossible. However, most visions share certain common themes important to this examination. These themes include:

- Adversaries knowing our fighting doctrine and current (and developing) capabilities will avoid our strengths and exploit our weaknesses. Asymmetric approaches to maneuver combat (such as seeking battle in urban areas) are expected. ${ }^{1}$ Importantly, beyond 2015 there is a real possibility of the emergence of a major military competitor who within a 
specific region, could openly offer battle with technologies and methods similar to our own. ${ }^{2}$

- The near-term "digitization" of major U.S. field units will make the widespread dissemination of information via computer and advanced radio networks possible. These advances are predicted to provide "real-" and "near-real-time" information on threat and friendly locations, and friendly planning/logistics information. We can expect many potential threat countries to gain similar capabilities in the mid-term.

- A decrease in the number of U.S. divisions, and numbers of elements and systems within divisions will occur. This drawdown would be driven by reduced defense spending, increased equipment costs, and transportation constraints associated with force projection. In the near- to mid-term, the existing force will be a mix of legacy system units and digitized units. In the far term, the mix will consist of digitized units (now the campaign units) and AAN units that are far lighter and more lethal. ${ }^{3}$ These AAN units are projected to have far better battlefield speed and strategic deployability than current forces. $^{4}$

- A continued increase in types and numbers of sensors and precision guided munitions used by both U.S. and potential threat forces in operations.

- Increased urbanization in almost all parts of the world, and

- A continuation of a national security strategy of "engagement" and defense strategy of "shaping, responding and preparing".

\section{OUTLINE OF THE NEW DOCTRINE}

In broad terms, the advantages of digitization and the implications of precision munitions are discussed in Army field manuals, and Training and Doctrine Command 
(TRADOC) pamphlets and papers. However, the fighting doctrine (non-linear or empty

battlefield) evolving from these advances are outlined only in general terms with little detail

and no inference as to their implications in the political, public and joint (interservice)

domains. For the near- and mid-term (up to 2015), the U.S. Army's Training and Doctrine

Command (TRADOC) identifies our future doctrine as Force XXI operations:

[C]haracterized by non-linearity, executing tasks across the entire battlespace rather than massing combat power at the Forward Line of Troops (FLOT). Non-linear operations do not seek a rigid organization of the battlespace into close, deep, and rear operations. Instead, the battlespace is fluid... Non-linearity requires soldiers and leaders to possess greater situational awareness, allowing risk to be accepted with space between units rather than more traditional contiguous operations. Non-linearity also increases the requirement of each divisional element, maneuver, CS and CSS for all-around security. ${ }^{5}$

For the period of AAN (after 2015), whicle the battlefield and our doctrinal concept are

similar to those of Force XXI, an important addition is the concept of "preclusion":

The Fundamental challenge facing military planners, once the National Command Authorities (NCA) decide to use military force, is the race to establish military capability in the troubled theater. Efforts to resolve the crisis short of war will almost certainly cede the initial military initiative and advantage to the enemy. As U.S. or allied/coalition forward presence forces are reinforced...leadership seeks to wrest the initiative...the answer to this challenge is strategic preclusion...the idea of moving so fast and with such lethality that enemies cannot "set" forces and operate at advantage... this response would be decisive in its own right... at a minimum, its rapid arrival in theater would fundamentally alter the relationship of forces within the battlespace to our advantage and set the conditions for timely integration of additional forces...

... [L]ong range, precision firepower systems will maintain the defensive as the dominant form of warfare. To restore the advantage to the offensive, we believe that the Army must devise the means to accelerate the speed of movement across the deadly zone by an order of magnitude or greater. ${ }^{7}$

The ability to get into the theater "firstest with the mostest" reduces risk to forces first to arrive and prevents the enemy from setting himself into an advantageous defensive position. Early arrival will change the elemental patterns of war at the theater level. Such a campaign will allow near simultaneous rather than sequential applications of both killing power and maneuver. Strategic speed will allow a theater war to take the form of a coup de main.

We will continue to rely on technology to offset inferiority in numbers. The smaller force combined with improvements in targeting, precision munitions, and situational awareness allows and drives us to disperse. The benefits of dispersal, however, don't come 
without inherent military risks, risks complicated by early insertion in theater (preclusion).

With this introduction to our future environment and doctrinal concepts, parallels can now be seen in the German campaign.

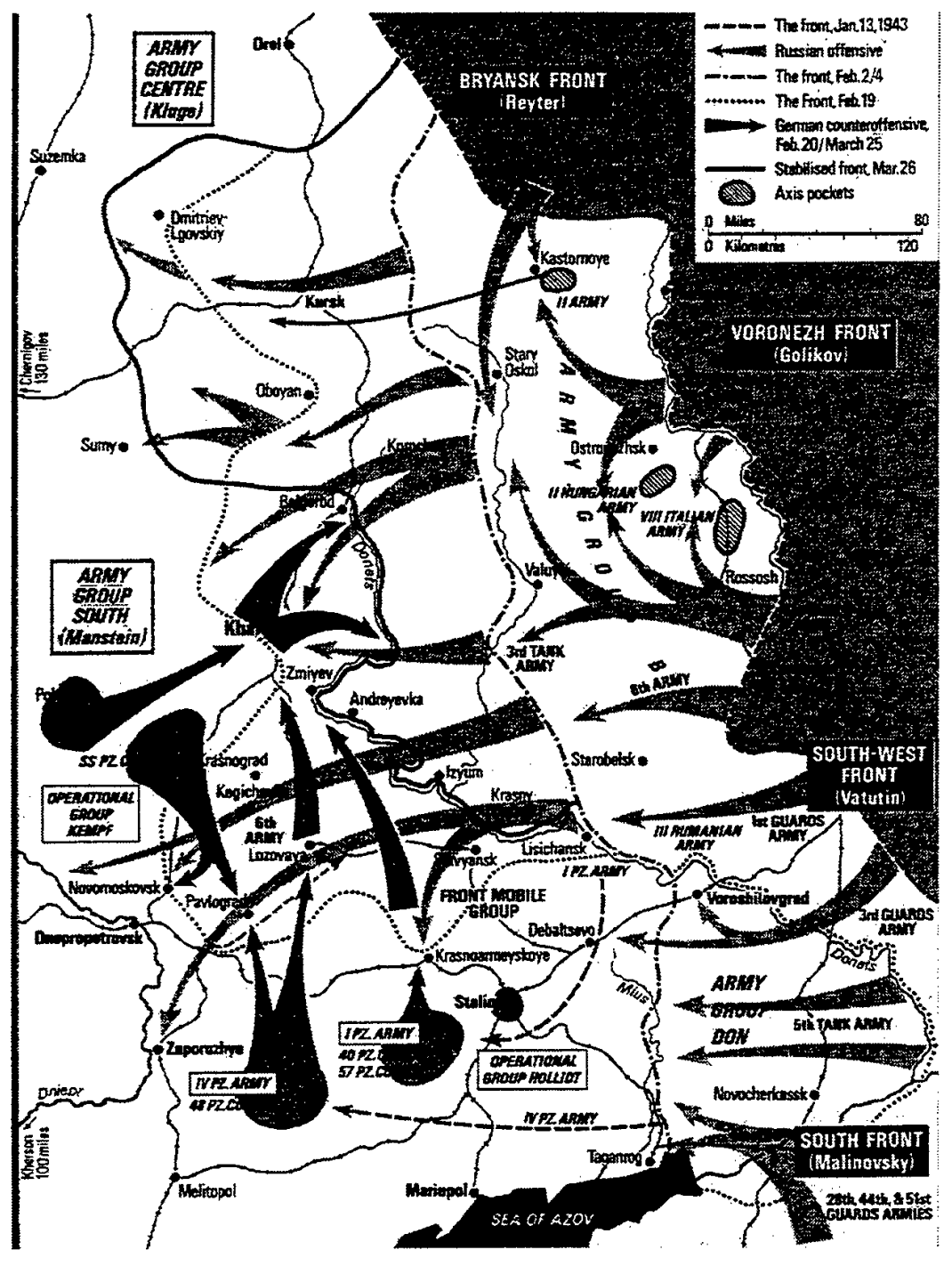

Figure 1 Army Group South Area of Operations
The Miracle of the Donets - the German Campaign

The Setting

December 1942 -

the fate of the German Army at

Stalingrad is all but sealed with

the failure of German relief

operations. Soviet forces

regroup and contemplate their

next move as they continue to

pressure German and allied units

along the entire front. German

and allied forces are arrayed in

an elongated front with

Hungarian, Italian and Romanian

forces - required allied forces

because of a shortage of German units - holding the critical and assailable central region of the German southern wing (see Figure 1). This wing, consisting of Army Group " $\mathrm{B}$ " in the north (located vicinity Stary Oskol, but not shown in Figure 1 as it was removed from the front and its forces split between Army Groups South and Center on 23 January), Army Group "Don" in the south-center (renamed "South" on 23 Jan), and Army Group "A" in the Caucasus 
far south of Rostov (not shown). Lastly, German forces in and around Stalingrad (off map to the east), although fated for defeat, are tying down significant Soviet forces.

Stalin, euphoric with his expected victory at Stalingrad, wanted a continued offensive to complete the destruction of the German southern wing. The Soviet General Staff and Intelligence Service agreed, correctly viewing German forces as tired, depleted, in disarray, and strung out along a largely undefendable front. With favorable force ratios of 7 to 1 in most areas, Soviet planning that winter developed into three overlapping and intertwined operations: "Little Saturn", "Gallop" and "Star". Respectively, their objectives were the destruction of the Italian and Hungarian Armies to open a gap in the northern portion of the southern wing; the liberation of the Donbas region toward Rostov and the Dnepr River (including the destruction of Army Groups Don and A); and the liberation of Kharkov and regions as far west as possible. As planned, Soviet forces participating in these operations, although having a significant superiority of forces, would continue operations without any pause (the worn down and depleted Soviet units were to have an increasingly detrimental effect as the battle unfolded).

German Field Marshal Erich von Manstein (often considered the most capable of World War II German generals) having recently taken command in November, was reacting to the Soviet onslaught and ultimately coordinating the southern wing's actions. He immediately recognized that more than just the $\mathrm{VI}^{\text {th }}$ Army (at Stalingrad) was at stake. Predicting Soviet drives to the south and

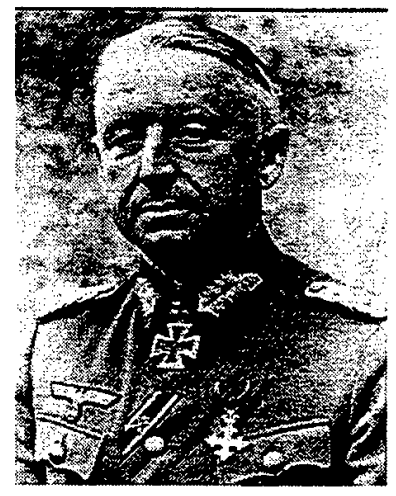

Figure 2: Field Marshal Erich von Manstein southeast, he perceived the danger to the entire southern wing, and in turn, the entire Eastern Front. 
Given the situation, von Manstein had few advantages, but one proved to be critical

for validating his predictions and allowing him to act boldly - the German tactical intelligence

system that was able... in today's sense...to provide "near perfect" intelligence.

As described by General Blumroeder, G2 of Army Group South:

The estimates of the Army Group were based on that of the overall intelligence service which used different sources. First, there was communications reconnaissance which was extraordinarily successful because of the fact that the Soviet were often very flippant on their communications nets. The second source was air reconnaissance, although that depended very heavily on weather conditions. The third source was the interrogation of prisoners of war, especially those of high ranks (for example, the deputy commander of the $1^{\text {st }}$ Guards Army was captured and interrogated). Fourth, there were captured documents, in particular, the operations orders of enemy forces.... This produced good results on enemy force structure, on the types of units, and on enemy intentions. ${ }^{9}$

The confluence of von Manstein's confidence in his prophecy of Soviet intentions, and his near perfect, constantly updated intelligence provided the clarity that would allow the Germans to take risk where none would have been considered and apply pressure where most effective. The German situation is uniquely analogous to circumstances envisioned in today's emerging U.S. concepts - "Expanding situational awareness...frees the commander to distribute maneuver against critical objectives instead of supporting other maneuver elements. ${ }^{.10}$

\section{The Soviets Press Their Advantage}

Beginning in mid December,

Soviet General N.F.Vatutin's

Southwest Front struck the III $^{\text {rd }}$

Rumanian and VIII ${ }^{\text {th }}$ Italian Armies

(then supported by three German

divisions). Executing Little Saturn

...Advancing rapidly, they [the Russians] annihilated in quick succession the Romanian, Italian, and Hungarian units along the Chir and Don Rivers and opened a $\mathbf{3 5 0}$ mile gap in the German front. This breach was equal to the total length of the western front in World War I. Initially, only isolated German divisions, committed in support of allied and satellite forces, stood in the way of the Russians, like the stays of a corset.

- German General Erhard Rauss, Commander 6th Panzer Division, German Defense Tactics Against Russian Breakthroughs

substantially as planned, by 30 December a deep penetration 80 miles wide had destabilized 
the entire northern and central section of the southern wing, setting the preconditions for the Soviet General F.I. Golikov's Voronezh Front to execute the Gallop plan.

On 13 January, Golikov's Front successfully penetrated and decimated the II ${ }^{\text {nd }}$ Hungarian Army, completed the destruction of the VIII ${ }^{\text {th }}$ Italian Army, and created a 150 mile breach in Axis defenses (allowing continued operations under the Star plan). The width and depth of Vatutin and Golikov's penetrations posed a major threat to German forces throughout the entire southern wing.

Given the trickle of reserves arriving and the need to protect the lines of communications of Army Group A (still deep in the Caucus), von Manstein saw that the salvation of a greatly outnumbered southern wing would have to be based on a highly mobile defense. If managed properly, the defense would be able to hold tightly to a few critical sectors, deliberately take risks in others (withdrawing units to generate sufficient reserves), and then mount a coordinated counteroffensive against wornout Soviet penetrations. But this vision was hampered by three significant problems:

- Initially, the lack of any fresh combat forces

- The need to protect the northern flank of Army Group A - still engaged 200 miles to the southeast of Rostov, and

- Hitler's intervention. Having little expertise in operational art, Hitler failed to recognize the southern wing's danger and was characteristically resistant to any discussion of withdrawal from conquered territory regardless of the potential for future victory - holding ground was the preeminent national strategy. 


\section{The German Counterstroke Takes Form}

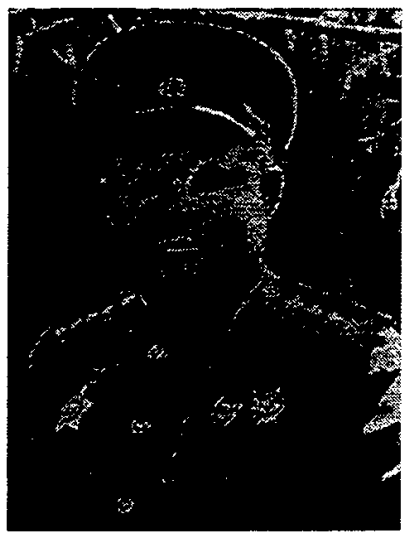

Figure 3: General N.F. Vatutin

With Vatutin's offensive, the Army Group found itself in a highly precarious situation. In the north, Armee Abteilung Fretter-Pico (an adhoc multi-divisional group lead by General Fretter-Pico) held blocking positions along the northern Donets and in front of Kamensk. In the south, Armee Abteilung Hollidt stabilized the situation along the Bystraya River (not shown in Figure 1 but in the vicinity of Novocherkassk). Between these battle groups a huge gap, caused by Vatutin's offensive remained open. South of the Don, Generaloberst Hermann Hoth's IV ${ }^{\text {th }}$ Panzer Army was fighting a losing battle to hold the lines of communications open for Army Group A.

The lines were just too long for the forces available. Although the far flanks were stabilizing, in most areas there wasn't a front but rather a series of blocking positions chosen to stop or slow Soviet advances. This extreme situation called for extreme solutions as von Manstein tried to set the conditions for the German counterstroke. Hitler, in shock from the impending loss of Stalingrad (which would occur on 2 February) allowed von Manstein a few weeks in which to fight the mobile battle he wanted. With the outstanding intelligence being provided on Soviet dispositions, the Army Group could denude areas of the front in order to create the armored reserves capable of striking back when an opportunity presented itself. Essentially, the Army Group had been forced to

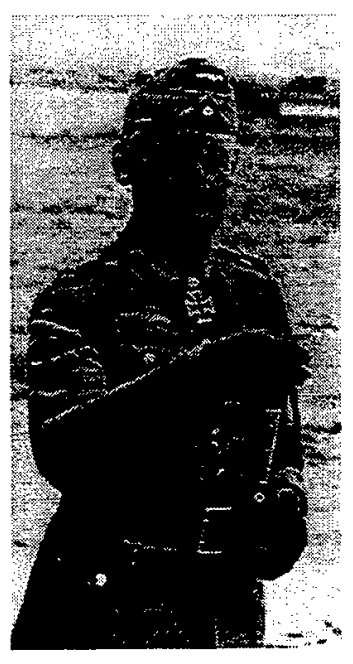

Figure 4: Generaloberst Hermann Hoth 
"Simultaneous, nonlinear, distributed maneuvers" like those called for in our current U.S. conceptual documents. ${ }^{11}$

... If Hitler thought he could order us, in the face of that preponderance of forces and with such an expanse of territory to cover, to make the army hold some 'line' or other, or else to obtain his approval before undertaking any withdrawal, he was seriously mistaken... As things now stood, Fourth Panzer Army's object was not to offer inadequate resistance along an over-extended line, but to keep its forces close together. Only thus could it offer strong opposition at vital spots or deal the enemy a surprise blow whenever an opportunity presented itself. At times it would obviously have to denude parts of its area completely and be content to cover others with only a flimsy defense screen... Like the $4^{\text {th }}$ Panzer Army, Army Detachment Hollidt reflected the firm yet versatile leadership.... Here, too, however, the Army Group assumed ultimate responsibility by ordering it, at great - if not immediate risk to the spots thus laid bare, to bunch its armour together for short offensive thrusts.

\section{- Von Manstein, Lost Victories}

With the continuing crisis, Hitler finally allowed Army Group A

(still in the Caucus) to withdraw slowly and transfer the $1^{\text {st }}$ Panzer Army to Army Group South. But by 7 January, the Soviets were within thirty miles of Rostov and the severance of Army Group A from the rest of the German front seemed imminent. Hoth's $\mathrm{IV}^{\text {th }}$

Panzer Army desperately fought to hold open the $1^{\text {st }}$ Panzer Army's door through Rostov as it evacuated the Caucus, and at the same time, to delay the Russian advance south. With the arrival of the $\left.\right|^{\text {st }}$ Panzer Army forces north of Rostov, Vatutin's and the Soviet South Fronts drives on Rostov and the Mius River region were slowed and then stopped. As things were stabilizing in the south, Golikov's offensive in the north began to widen the existing gap within the Army Group and create a new one near Stary Oskol and Kornchir.

The confluence of Vatutin's and Golikov's offensives clearly threatened the German southern wing. Now one of two basic philosophies would have to guide German offensive operations and how reinforcements would be used. The conservative one, supported by Hitler, called for using available forces to save as much territory as possible by intercepting the Soviets as far forward as possible. The other, von Manstein's concept, would allow a 
continued Soviet penetration, taking time to form two strong German concentrations on the breakthrough's flanks, and then cut the penetration off. The first choice, a linear plan, would stabilize the front without inflicting significant losses to the Soviets. The latter, an inherently riskier and non-linear approach, promised significant losses to the Soviets and an incidental reoccupation of land to the 1942 limits - a decisive military victory. This fundamental difference between the military and the political philosophies would impede planning and execution throughout the balance of the campaign.

The Germans' non-linear approach had hidden costs. Without the relative security of a forward line of troops, the Soviets exploited the gaps to move various size groups through the line and create havoc in the rear. As stated by German General Mellenthin, then the operations officer for the $48^{\text {th }}$ Panzer Corps:

Practically every Russian attack was preceded by large-scale infiltrations, by an "oozing through" of small units and individual men... However much of the outlying areas were kept under observation, the Russians were suddenly there, in the very midst of our positions; and nobody had seen them come, nor did anybody know whence they had come. ${ }^{12}$

Each rear area support element was responsible for its own security and was often, to the detriment of the front line, given combat units for direct support. Significantly, to assist in countering small unit infiltrations and partisan activity, each Army Group Rear Area Headquarters was generally "allocated three security divisions... [which] consisted of one infantry regiment and an artillery battalion....[with] their primary tasks [being] the security of supply installations, supply routes and supply material...."13 Clearly, this level of rear area support improbable in today's U.S. Army doctrine. ${ }^{14}$

Throughout the period, fighting side by side with the Army was the ever-present Luftwaffe, providing extensive and critical support to ground units - support that artillery units were often unable to provide due to the gaps between units, artillery losses, and the far flung 
interjection of German and Soviet armored units. As stated by Luftwaffe General Hermann Plocher:

... In every area the threat of new soviet offenses loom ominously, and the weak air forces available were daily committed to action in support of the hard-pressed German armies as well as in constant battles against an overwhelmingly superior air enemy. ${ }^{15}$

Masterfully shifting air units across the front, and without air superiority, the Luftwaffe allocated $80 \%$ of its sorties to close air support/interdiction missions (termed "tactical cooperation with the Army") ${ }^{16}$ - a level of ground force support, dedication and risk taking, implausible in current U.S. doctrinal and conceptual papers.

By 31 January 1943 most major units of $I^{\text {st }}$ Panzer Army had passed through Rostov, and on February 6th von Manstein was finally permitted to withdraw to the Mius River (in the south) thereby releasing desperately needed troops for the counterattacks to come. With the shortening of the line permitted by this move and arrival of forces from the West, the Army Group began forming three major concentrations for a counterstroke. The first two in the south vicinity of Krasnoarmeyskoye, and east of Zaporozhye $\left(\mathrm{I}^{\text {st }}\right.$ and $\mathrm{IV}^{\text {th }}$ Panzer Armies respectively) and the third being formed by the SS Panzer Corps (then arriving from the West) in the north vicinity of Krasnograd and Poltava. In the German plan being finalized, these forces, driving north and southeast respectively, would cut off the Soviet penetration and drive on to regain the Donets River line and defacto, Kharkov. But this plan was predicated on the continued advance of Soviet forces through the extensive gap in the center - a planned territorial abandonment that Hitler found increasingly difficult to tolerate.

\section{Political Intervention Endangers the Campaign}

With the withdrawal to the Mius River line, the $\mathrm{IV}^{\text {th }}$ and $\mathrm{I}^{\text {st }}$ Panzer Armies moved from defensive positions east of the Mius River directly to assembly areas leaving Army Abteilung 
Hollidt to defend the region from Voroshilovgrad to the Sea of Azov. The streaming westward of $I^{\text {st }}$ and IV th Panzer Armies (moving to assembly areas), and the continued advance of Golikov and Vatutin's forces seemingly validated what the Soviets wished to see, the German's headlong retreat.

With the continued Soviet drive in the north, Kursk would fall on 7 February. There, against Hitler's explicit orders, SS forces evacuated Kharkov on 16 February. Unable to tolerate the loss of the Soviet Union's fourth largest city for "political reasons", he ordered the immediate retaking of the city by the balance of SS Corps then arriving from the west - an order which von Manstein would resist. In the south, by 12 February, the Soviets were within 100 miles of Army Group South headquarters at Zaporozhye, but, as von Manstein had predicted, their drive was running out of steam.

As Hitler recovered from the loss of Stalingrad, von Manstein's seemingly headlong loss of territory and his independence of mind as to the future course was more than Hitler could tolerate. The day following the fall of Kharkov, Army Group South was told to expect an immediate visit by Hitler. Arriving at Zaporozhye (the closest Hitler had ever approached any front during World War II - except for Berlin's fall) on 17 February, he had resolved to dismiss von Manstein. Hitler, convinced forces should be used to immediately stop the Soviet advance and retake Kharkov, couldn't understand how von Manstein could request additional units when half his forces and three quarters of his armor weren't even engaged at the time (as they massed for the counterstroke). The IV ${ }^{\text {th }}$ Panzer Army had been out of action for two days, and the $\mathrm{I}^{\text {st }}$ Panzer Army had only one division engaged. To Hitler it was a plan gone mad - known Soviet forces being allowed free rein while German forces sat in assembly areas. Only after two days of heated discussions was von Manstein allowed to 
continue planned operations when it became clear the threat was too great to change plans in mid-stream - the Soviets now were within 30 miles of Zaporozhye (where Hitler was) and the Dnepr River crossings. ${ }^{17}$

\section{The German Counterstroke}

By 18 February, almost all was ready. In the south, Hoth's IV th Panzer Army (assigned overall responsibly for attack coordination) and the other units participating (the highly degraded $48^{\text {th }}, 40^{\text {th }}$ an $57^{\text {th }}$ Panzer Corps) were in position southeast of Zaporozhye and west of Stalino. Army Abteilung Hollidt continued to hold the southern shoulder of the Soviet penetration. In the north, the SS Panzer Corps (with one division holding the northern shoulder of the Soviet penetration) was also massed and in position.

On the $19^{\text {th }}$, German forces started their attack from the north and south achieving complete surprise. Soviet forces - drained, surprised, and flanked - folded like cards. Knowing Soviet positions and status, in the next week German forces shattered the $40^{\text {th }}$ Army, $3^{\text {rd }}$ Tank Army, $6^{\text {th }}$ Army, and the 1 st Guards Army as well as several independent armored groups. By the first week of March, the Donets had been reached and on 9 March, German forces reached the outskirts of Kharkov. There, mindful of his shortage of infantry, and against tying down troops in street fighting, General Hoth had planned to encircle the city, cutting Russian lines and forcing their surrender. However, against explicit orders, the SS Corps sent two divisions into the city, taking it after three days of costly fighting. ${ }^{18}$ With the loss of Kharkov, essentially all Soviet resistance in the Donets collapsed - the Voronezh Front, like the Southwestern Front, withdrew remaining forces to the far side of the DonetsMinus line. 
The counterstroke concluded, the Germans counted over a thousand captured guns, 615 tanks but only 6000 prisoners (resulting from a shortage of infantry and subsequent inability to seal the battlefield). The Army Group and the southern wing had been saved from annihilation.

On reflection, von Manstein attributed the German's recovery and victory to two general factors: Soviet inability to coordinate strength and speed at the operational level, and the almost superhuman achievements of German commanders and troops.

The German fighting troops, convinced of their superiority as soldiers, stood their ground in the most desperate situations, and their courage and self-sacrifice did much to compensate for the enemy's numerical preponderance. ${ }^{19}$

\section{LESSONS AND IMPLICATIONS FOR NEW U.S. CONCEPTS}

"The miracle of the Donets" was a campaign set and won not by the might of forces fighting from a conventional front line, but by skilled commanders, staffs and soldiers using detailed intelligence to manage forces - defending, forming, and striking in an recurrent nonlinear manner. A style closely akin to those envisioned for use by Force XXI and Army After Next units. The campaigns conduct points to lessons and implications in six areas for our future Army to resolve:

- Reliance on Allies and their warfighting capabilities

- A Required transformation in civil-military relations

- Political and media impacts to operations - shaping the media environment

- Mismatch between the American way of war and non-linear concepts

- Mismatch in Army and Air Force concepts and doctrine

- A Decline in "rear area" security

\section{Reliance on Allies and Their Warfighting Capabilities}

Given the German's situation in the campaign, they relied on less capable allies to support their extended line - a reliance that doomed an Army and almost cost the entire 
southern wing. In the future, a smaller U.S. Army - one envisioned in both the near and far term to initially deploy a relatively small force (followed months later by Campaign forces) will have similar troop shorfall and require similar reliance on multinational support.

Short of full mobilization in major operations, the U.S. won't be able to deploy sufficient forces in the proper time to conduct more than one or two of the following missions:

- Form a linear defense on part of a border

- Defend logistics and medical personnel (no longer defended by the relative security of a front line)

- Defend or take back a city, and

- Conduct offensive operations.

We will be forced to rely on large augmentations by multinational forces - not because it's "politically convenient" as it is today, but because it's a necessity. This shift conflicts with current documents like the Quadrennial Defense Review, which clearly states "...the United States will retain the capability to act unilaterally..." ${ }^{n 20}$ and obviously, incurs risk for both Force $X X I$ and $A A N$ units.

The campaign on the Eastern Front clearly shows that assigning important missions to partners with greatly inferior capabilities is a formula for disaster. With the improvements expected for our future Army, a greater divergence in capability between our and allied armies will likely create a situation more similar to the German example than we would like. Disparity of capability will give the enemy several obvious opportunities to exploit our weakness. He could strike at multinational forces already in theater, making the insertion of our lead forces highly difficult or impossible. Or, after the arrival of our forces, the threat could attempt to initially avoid combat with U.S. units and strike at the allies - as the Soviets repeatedly did against the Germans. 
In an attempt to reduce future risk, we'll rely more on multinational partners, yet the growing disparity in method and capability between our forces and our partners will cause a different but equal risk. Only a change in funding and policy to support additional force structure will prevent us from having to ... if the United States pursues what might be called "qualitative" coalitions based on a synergistic division of labor among the participants rather than "quantitative" coalitions where all the forces involved have similar capabilities. Of course, qualitative coalitions create mutual dependencies among their participants, so only nations that trust each other deeply would allow them to develop. And in the case of a global power, it would be difficult to structure several regional coalitions each with a division of labor similar enough to achieve such efficiencies.

- Strategic Studies Institute, The Future of American Landpower: Strategic Challenges for the $21^{\text {st }}$ Century Army

increasingly rely on our partners. Can

we convince decision-makers, the public and ourselves that reliance on coalition forces is a prudent risk given growing inequalities between allied capabilities and ours? If we can convince them our government must gain and maintain appropriate military partners in each potential conflict area.

Discussions of the U.S. forming headquarters and communications liaison teams to attach to coalition partners for operations are a good start at bridging this capability void and helping to alleviate this risk. To make future partners truly employable, further U.S. force structure will need to be allocated for fire support augmentations and other specialty units. But by building these supplemental units, we'll again in part negate the force structure saving expected from non-linear warfare.

\section{A Required Transformation in Civil-Military Relations}

Hitler's philosophies and positions were the embodiment of German national strategy in 1943. His insistence on equating even short term losses of territory with loss of national prestige was one of von Manstein's most significant problems and was at odds with any type of fluid non-linear warfighting concept. Whether it's a large-scale advance of enemy forces, 
... [Hitler] fought shy of risks because of their inherent threat to his prestige and who, for all his talent, lacked the groundwork of real military ability... [and] On the other side stood the views of the military leaders who by virtue of their education and training still firmly believed that warfare was an art in which clarity of appreciation and boldness of decision constituted the essential elements.

- Von Manstein, Lost Victories large-scale infiltrations of small units, or friendly delays in taking cities, the U.S. military can't automatically expect political

leaders to allow the military to trade space and time for eventual victory. A tenuous relationship such as that which existed between Hitler and von Manstein- a conflict based on the political leader's military ineptitude and a military unable to guide or educate its civilian leaders isn't acceptable.

Given their inherent risks, Force XXI and AAN operational concepts require more than ever an unbreakable trust between the military and its political leaders. Although not an issue for our fighting manuals, the need for building trust and familiarizing our political leaders with our fighting concepts is seemingly missed in all conceptual writings. Political leaders who are familiar with and accept military concepts will weather the bad times and the media storms that will occur during operations. We must start now to build and maintain this foundation if our future concepts are to be viable.

The concepts of preclusion, "supremacy of the defense" and getting there "first with the most" are critical to setting the conditions for using non-linear concepts in the AAN period. In our example, we saw that Hitler, a dictator with absolute power, wavered in making decisions critical to successful operations. In our democratic structure, it is unlikely we can expect a better response when the gaining of consensus (congressional and public) before engaging troops is the foundation of forming and executing national strategy. Yet as written in our concepts, the President must authorize immediate deployment in a crisis or we 
are at an extreme handicap. There is little or no time for gaining consensus at home or for negotiation with multinational partners or enemies.

Just like the German leaders of 1914, either mobilization (or today deployment) must be immediately authorized or we could lose the conflict. Seemingly, our military tempo will outstrip diplomatic and political condition setting. We must establish for our political leaders a coherent and recurring familiarization program explaining our methods, our rationale and the actions political leaders must perform to make our doctrine work. Without some fundamental change in civil-military relations that could bring this about, we must ask if we are offering our civilian leaders an unexecutable operational concept.

\title{
Political and Media Impacts to Operations - Shaping the Media Environment
}

The media environment is already an important planning consideration in today's doctrine. Our future concepts put us at even greater potential risk of having media and political intervention in military operations. As stated in FM 100-7, Decisive Force: The Army in Theater Operations,

\begin{abstract}
A key factor that must be considered at the strategic, operational, and tactical levels is the presence of national and international media representatives and the effects of global visibility on the planning and execution of operations. Leaders must understand that the perception of an operation can be as important to success as the actual execution of the operation. Leaders must recognize that the global visibility of today's media is bridging the gap between the strategic and tactical levels, so that a tactical victory can be an operational or strategic loss and vice versa. ${ }^{21}$
\end{abstract}

In the German campaign, the Soviets overwhelmed the front, penetrated hundreds of miles and occupied several major cities as the Germans recovered and "cocked" to strike. Having absolute power and censorship, Hitler didn't face the storm of public outcry a democracy can expect today if suffering such heavy losses. Non-linear operations, in offense and defense, inherently imply not defending or securing every yard of territory. Therefore, we must expect to directly and indirectly yield cities and territory as we set the 
conditions to strike - risking the potential wrath of the media and public. In addition, it will often be the host nation's territory we'll be trading. We must consider its effect on their will and morale when it's perceived the U.S. will sacrifice their homeland for a later victory.

Another factor to be considered is our extreme aversion to casualties and setbacks an aversion that presents our enemies asymmetric means to strike us (a la Somalia). For

...political leaders, the media, and the public are likely to remain fairly intolerant of protracted or costly military ventures except when crucial national interests are clearly threatened. American military operations must thus continue to be conducted as quickly as possible and result in as few casualties as feasible.

- Strategic Studies Institute, The Future of American Landpower: Strategic Challenges for the $21^{\text {st }}$ Century Army example, if an enemy force quickly

crosses an allies' border and occupies an urban area before U.S. forces can intervene that could present us with a no-win situation.

There, multinational forces may be incapable of dislodging the enemy without help. Upon arrival, the small U.S. strike force would be faced with two bad choices: do nothing until Campaign Forces arrive (being small with little depth or staying power), or conducting manpower intensive combat in an area where our sensor/digitization advantage is largely negated. In the city (jungle or mountainous regions could also cause the same affect), the enemy has picked the point where our greatest weaknesses merge with the loss of our advantages. The "meat grinder" of street fighting combined with other media "events" in and around the city could easily strike at our national will. Action or inaction strikes at U.S. and coalition prestige - a problem analogous to German situation when both losing and retaking Kharkov.

Like in this city scenario, either side's actions have the potential of undermining our public and political support - resulting in demands for specific military action (disrupting our battle plan) or demands for pullout. If this occurs before our forces can come to closure with 
the enemy, stalemate amounting to strategic success or outright victory for the enemy could result. Just as Hitler's desire to quickly retake Kharkov almost cost von Manstein his best counterstroke force (the SS Corps), can we win in a future war's second week if we've siphoned our best troops to retake towns or borders because of public and political pressure in the first?

Clearly the significance of public affairs and civil affairs planning and actions will be far greater than today. "Shaping" media coverage and how we relate current events to future successes will be critical. The Army must start planning the "hows" of preparing our leaders for the political impacts of the enemy's actions, and methods or media responses that can alleviate their effects.

\section{Mismatch between the American Way of War and Non-Linear Concepts}

In the last hundred years, the American way of war has been based on overwhelming force - clear mass and material advantages that have made us a military reluctant to take risks. Driven by necessity, the Germans couldn't follow this philosophy. As von Manstein stated earlier, "warfare was an art in which clarity of appreciation and boldness of decision constituted the essential elements" - just enough troops at just the right place. As time passes, the proliferation of technology, the growing threat of major competitors and a smaller Army will drive our concepts toward the German model.

By education and experience, the German way of war more naturally allowed the changeover from a large to a smaller force and from linear to far more risky non-linear warfare. Clearly, our future concepts are expeditionary in nature; small numbers quickly placed at the critical spot. Non-linear warfare means dispersed operations, gaps between units, with the inherent trust and risk associated with relying on intelligence, technology and 
fellow soldiers. With these concepts, we are taking two bold steps. Institutionally, because of a century of overwhelming force, America doesn't train its military or political leaders to routinely use risk to gain advantage; yet our new concepts rely on "audacity of concept and ruthless execution" for proper implementation. ${ }^{22}$ In an armed ... The tolerance of risk varies among nations involved in conflict... discerning the tolerance level - acceptable risk - is thus a vital military planning function at the strategic and operational levels.

- Dr. Steven Metz, Analyzing Strategic and Operational Risk

force that tends toward "zero defect"

in both training and execution, can we expect to change our philosophy quickly enough to match our new concepts and force structure? As military planners we must understand the level of risk our institution and its members can by nature accept. If the level is unacceptable, we must find means to alleviate it.

It's a world of just-enough forces, just in time - a state of mind to be impressed on our leaders. Even a badly translated thought by German Colonel Brandt (during an Army War College Art of War Symposium on this very German campaign) insightfully unveils the issue.

Last week my students and I were at the Fuhrungsakademie and participated in a corps exercise. At the end of the exercise one of the primary critiques was that recognizing the element of chance or forging an opportunity, making a chance [was needed] in order to get away from ...a conservative solution because it is going to be the approved solution... And the condemnation of their course of action was that [if] you did not seek chance, you did not recognize chance, you did not attempt to create the opportunity to open things up and to be innovative... ${ }^{23}$

Clearly, training non-linearly means "training risk" to set the conditions for success. In

...Simultaneous, nonlinear, distributed maneuvers now define decisive maneuver more than ever before... maneuver elements operate against objectives without positional reference to one another. Smaller, more mobile, and vastly more lethal Forces lend themselves to operations that engage numerous decisive points simultaneously. Expanding situational awareness...frees the commander to distribute maneuver against critical objectives... the schoolhouse, at the National

Training Center, in the Battle

Command Training Program and

in other exercises, we should

"frame risk-taking" to set the

- Operations, Revised Final Draft, 
conditions for success. As in German operations, in training U.S. units should be forced to fight outnumbered, fight non-linearly, and apply forces at the right point. These beliefs, clearly outlined in draft doctrine, aren't yet included in the design of upcoming Force XXI tests and demonstrations. ${ }^{24}$ Their inclusion is critical to developing our concepts and our leaders.

\section{Mismatch in Army and Air Force Concepts and Doctrine}

As validated by the German's non-linear warfighting, distances between units, difficulties of artillery support and the need to rapidly reinforce ground units required extensive close air support and interdiction. The Luftwaffe put $80 \%$ of its resources into ground support without having air superiority - a clear mindset of supporting the Army no matter the risk. For Army rotary wing assets, there is a similar conviction. However within the Air Force, the mindset is clearly to gain air superiority first, even at the cost of ground force survivability and effectiveness. As stated in the Air Force's capstone doctrinal manual:

\footnotetext{
...Air and space superiority rarely is an end in itself but is a means to the end of attaining military objectives. It is an important first step in military operations. [original document in bold]. ${ }^{25}$
}

The manual later states: "Superiority, even local or mission-specific superiority, may provide sufficient freedom of action to accomplish assigned objectives." ${ }^{26}$ However, this line appears to be written as an afterthought, and within the manual's context, can be interpreted as having little real relevance to the Air Force's implied dictum of theater air superiority first no matter what it takes. The Army already relies on service interdependence to make its doctrine work. ${ }^{27}$ This interdependence is greatly accentuated, as smaller, more measured forces, are placed in harm's way. Just as the Army's new concepts require its forces to inherently accept more risk, so must the Air Force's future doctrine. 
Our far-term concepts take interdependence to an even higher level. During the early stages of deployment, the Army has the least organic fire support and would rely heavily on the other services, especially the Air Force, to provide that capability. As we move toward "preclusion" and faster ground force projection, the earlier we get into theater - the less likely we'll have air superiority. Institutionally, the Air Force will allocate the preponderance of its resources to gain it. The time the Army needs the most support is when it can least rely on it. To provide adequate support, the Air Force must be willing to put precious aircraft and pilots at risk - the Air Force must be willing to support the Army with or without air superionity.

\section{A Decline in "Rear Area" Security}

The movement of large-scale friendly forces in a "sea" of unsecured territory will call for changes in tactics, techniques, and procedures not only for the Army, but also for joint partners supporting operations. Without a Friendly Line of Troops (FLOT) and its relatively secure rear area, significant interference in movement and support activities must be assumed. To date, the military implications of this shift aren't being addressed in Joint vision and Joint doctrinal papers and pamphlets. As with the Germans, the possibility of large scale enemy infiltrations or "stay behinds" present the force security issues including:

- Air and ground resupply points, and logistic routes

- Maintenance and medical activities

- Loiter areas for sensor and command and control platforms such as JSTARs, AWACs, and Guardrail Systems

- Loiter areas for close air support (CAS) aircraft

Without the security the FLOT affords, forward resupply, medical and maintenance elements will often require either organic or attached security units if they are to accomplish their missions. Each unit inside "the wire" will require security support - each element leaving the wire will also require it. The Germans resorted to security divisions and ever-present 
escorts from front line units - each security requirement eating away at the combat power available for operations. Over the last two years, the Army's Training and Doctrine Command's (TRADOC) computer simulations of future non-linear combat have validated this need. More than a quarter of available combat forces were needed for security duties in a non-linear environment. ${ }^{28}$ Frequent moves and reducing demand in fuel and ammunition can help to alleviate the problem, but clearly security will negate a portion of the force saving expected from non-linearity and points to possible threat asymmetric means to deflect combat power and inflict casualties.

Air and ground early warning and surveillance aircraft (such as AWACS, JSTARS and Guardrail) rely on an area secure from potential air-to-air and surface-to-air threats. Without a FLOT, this security can't be guaranteed (unless suitable bodies of water are available). In the future, we can expect mobile and shoulder fired surface-to-air systems to acquire and reach these high value assets. If it's known that surface-to-air "killer" teams are in the region, will the Air Force fly? Even today the threat of a few anti-radiation missiles can cause AWACS/JSTAR type systems to shut down and back off. ${ }^{29}$ ' Couldn't we expect a threat to hold back some number of aircraft and surface killer teams to push back our "eyes" at a critical time? The Germans relied most on communication intercepts to gain situational awareness - an effort relatively unaffected by a counter-air or a fluid environment. Our most important means of gaining a big picture (other than periodic satellite support) is not so unaffected - a limitation striking at our concepts' foundation, that of fulfilling the increased and near absolute need for situational awareness. Again, without a change in the Air Force's perspective on air superiority and short term risk acceptance, we can't rely on the Air Force for the information critical to ground force success. If we can't rely on the Air Force, it would 
seem prudent for the Army to push for systems of its own to provide similar support (such as Unmanned Aerial Vehicles).

As with our sensor systems, on-call close air support (CAS, both fixed and rotary wing) require loiter areas and forward resupply points near expected engagement areas. The threat of surface-to-air systems will limit loiter area choices, potentially making aircraft less responsive to ground force needs. Unless the risk is ignored, or more security provided, the choice of secure air routes to and from a supported area will be limited - resulting in less timely CAS. Importantly, the issue of secure air routes also impacts the means by which we'll initially employ and then resupply portions of our non-linear force. Given that many of these concepts are air based, its another aspect needing examination.

\section{A CALL TO ACTION}

Viability and acceptability: these are the main issues to be answered as the Army moves forward with its concepts. Our doctrine writers, our force developers, and our Army leadership must resolve the many political and military issues that can be inferred from the German experience. Resources must be directed toward resolving or alleviating the outlined problems.

\section{Reliance on Allies and Their Warfighting Capabilities}

Given a future supported by a smaller force structure, our politically leaders must be informed and reminded that we're moving away from the ability to act unilaterally. The Government, as a part of our shaping strategy, must help the military by selecting and maintaining compatible coalition partners around the world. 
To offset growing inequalities between allied capabilities and our own, U.S. force structure must be modified to include communication, sensor, fire support, and other specialty "augmentation units" for attachment to multinational partners.

\section{A Required Transformation in Civil-Military Relations}

The military must establish for our political leaders a coherent and recurring familiarization program explaining our projected fighting methods and their rationales. This program should address:

- Capabilities and limitations of the proposed warfighting structure and methods for Force XXI and AAN. Discussions have centered on capabilities and seemingly glossed over intrinsic limitations and increased risk.

- The need for a fundamental change in the pace of political decision making so preclusion concepts will have a chance to work. If accelerating the political process in crisis isn't possible, the Army must provide an operational concept with a better chance of success for the Army After Next period.

\section{Political and Media Impacts to Operations - Shaping the Media Environment}

We must better emphasis in our military manuals the need for preemptive public and civil affair plans (nationally and internationally) - "shaping" media coverage and preparing our leaders for the political impacts of the enemy's actions.

\section{Mismatch between the American Way of War and Non-Linear Concepts}

Field manuals and concept documents must be expanded to provide several layers of detail on the "hows" of non-linear operations and early deployment so that we may better understand the implications both to the Army and to the other services. The critical transition 
of concepts-to-doctrine, especially in the midyears, requires the allocation of additional resources to our Combat Development and Doctrine offices.

Using more detailed concepts in the schoolhouse and in exercises U.S. units and leaders should be forced to fight outnumbered, fight non-linearly, and apply forces at the right point. A high-risk battlefield requires on-the-spot innovation. Institutionally we must teach and reward, as the Germans put it, "making a chance".

\section{Mismatch in Army and Air Force Concepts and Doctrine}

The Army needs to immediately begin a process of review and coordination with the Joint Staff and Services - especially the Air Force. Interdependence is increasingly critical all services must become willing to compromise method and accept greater risk for the Army's concepts are to work. If the Army can't rely on the Air Force, it should push for systems providing similar situational and close air support functions.

\section{A Decline in "Rear Area" Security}

The movement in a "sea" of unsecured territory will call for changes in tactics, techniques, and procedures for the Army and the other services. Issues include:

- How to secure forward resupply, medical and maintenance elements.

- Security of loiter zones for surveillance and close air support aircraft including an acceptance of short term risk to provide effective support to ground elements.

\section{CONCLUSION}

As the Army develops its future concepts, it must assess their political and military implications. Looking only at conventional mid- and high-intensity battlefield, a review of the German campaign demonstrates that non-linearity can be an exceptionally successful 
operational concept when combined with the employment concepts envisioned for Force XXI and Army After Next - but only feasible for the United States if the issues identified in the political and military domains are resolved.

To date, the Army has made developmental decisions that partially account for the future environment, but only from a "pure Army" perspective, ignoring the many problems that will surface as the concepts are resourced and executed. Discussions have centered on technological advances and opportunities, but have failed to fully explore the many implications of a smaller, non-linear force in the context of the American way of war, acceptable risk, joint interdependence, coalitions, staying power, surrendering of terrain, media impacts, and leadership options in time of crisis.

Because we knew we had to get smaller, exploring concepts like non-linear warfare have been advantageous because of their potential force savings. However, German operations clearly indicate security requirements and augmentations for multinational partners will largely obviate these reductions. The force saving we hoped for won't be there potentially requiring the Army to seek larger budgets to buy back force structure.

If our vision of defensive supremacy in the AAN period is correct, and our concepts require a fast-acting political leadership willing to take risks, we need to ask if this a "bridge to far". Reconciling the military and political tempo is the key. Failure to do so may require us to modify our concepts or seek other solutions - solutions that will require additional funding to make a plausible military strategy. Resolution is needed soon. We can ill afford in dollars or time to build a force and doctrine around ideas our political leaders will find unsuitable when it comes time for execution. A doctrine unacceptable to our political leadership is no doctrine at all. 
Do we, like Roland in the opening quote, need to learn that knightly courage used with prudence is one thing and folly is another? We need to look at our concept's second order effects and ensure we've allowed for the nature of our political process and that of the Army as an institution. If our concepts conflict with those natures we must expend significant resources to transform them, or we must rethink and change our concepts.

Word Count $=8356$ 


\section{ENDNOTES}

${ }^{1}$ Department of Defense, Concept for Future Joint Operations, Expanding Joint Vision 2010 (Washington, D.C.: U.S. Department of the Army, May 1997), 15.

${ }^{2}$ Department of Defense, Quadrennial Defense Review. (Washington, D.C.: U.S. Department of Defense, May 1997), 5. Department of the Army. Knowledge and Speed - The Annual Report of the Army After Next Project to the Chief of Staff of the Army (Washington, D.C.: U.S. Department of the Army, July 1997) 10. Department of the Army, The Annual Report of the Army After Next Project to the Chief of Staff of the Army (Washington, D.C.: U.S. Department of the Army, December 1998), 1.

${ }^{3}$ Department of the Army, Knowledge and Speed - The Annual Report of the Army After Next Project to the Chief of Staff of the Army (Washington, D.C.: U.S. Department of the Army, July 1997), 17.

${ }^{4}$ Department of the Army, Knowledge and Speed - The Annual Report of the Army After Next Project to the Chief of Staff of the Army (Washington, D.C.: U.S. Department of the Army, July 1997), A-5.

${ }^{5}$ Department of the Army, Land Combat in the $21^{\text {st }}$ Century, Training and Doctrine Command Pamphlet (unnumbered), TRADOC CDR's Black Book No 4 (Washington, D.C.: U.S. Department of the Army, 1996), document unnumbered.

${ }^{6}$ Department of the Army, The Annual Report of the Army After Next Project to the Chief of Staff of the Army (Washington, D.C.: U.S. Department of the Army, December 1998), 1.

${ }^{7}$ Department of the Army, Knowledge and Speed - The Annual Report of the Army After Next Project to the Chief of Staff of the Army (Washington, D.C.: U.S. Department of the Army, July 1997), 3.

${ }^{8}$ Department of the Army, Knowledge and Speed - The Annual Report of the Army After Next Project to the Chief of Staff of the Army (Washington, D.C.: U.S. Department of the Army, July 1997), A-5.

${ }^{9}$ Department of the Army, U.S. Army War College, 1984 Art of War Symposium, From the Don to the Dnieper: Soviet Offensive Operations, December 1942-August 1943, Transcript of Proceedings (Washington, D.C.: U.S. Department of the Army), 188.

${ }^{10}$ Operations, Revised Final Draft, 6-22.

${ }^{11}$ Operations, Revised Final Draft, 6-22.

12 U.S. Army War College, 1984 Art of War Symposium, 116.

${ }^{13}$ Department of the Army, Comparative Logistical Systems, U.S. Army Command and General Staff College, RB 54-2, (Washington, D.C.: U.S. Department of the Army, May 1961), 191.

14 Department of the Army, Corps Operations, Field Manual 100-15 (Washington, D.C.: U.S. Department of the Army, October 1996), appendix C-2.

${ }^{15}$ Plocher, Hermann, The German Air Force Versus Russia, 1943, USAF Historical Studies: No. 155, (Washington, D.C.: U.S. Department of the Air Force, June 1967), 267.

${ }^{16}$ Plocher, 230.

${ }^{17}$ Summarized from Matthew Cooper, The German Army (Lanham, MD, Scarborough House, 1990), 444. 


\footnotetext{
${ }^{18}$ Earl F. Erickson, Stalingrad to Berlin. The German Defeat in the East (Washington D.C.: U.S. Army Center of Military History, 1987), 97.

${ }^{19}$ Erich von Manstein, Lost Victories (Navato: Presidio Press, 1982), 441.

${ }^{20}$ Department of Defense, Quadrennial Defense Review (Washington, D.C.: U.S. Department of Defense, May 1997), 8.

${ }^{21}$ Department of the Army, Decisive Force: The Army in Theater Operations, Field Manual 100-7, (Washington, D.C.: U.S. Department of the Army, May 1995), A-12.

22 Operations, Revised Final Draft, 6-22.

${ }^{23}$ U.S. Army War College, 1984 Art of War Symposium, 308.

${ }^{24}$ LTC Bill Gerhardt, Deputy Director, Joint Venture Office, U.S. Army Training and Doctrine Command, interview by author, 18 February 1999.

${ }^{25}$ Department of the Air Force, Air Force Basic Doctrine, Air Force Doctrine Document 1 (Washington, D.C.: U.S. Department of the Air Force, September 1997), 29.

${ }^{26}$ Air Force Basic Doctrine, 29.

${ }^{27}$ Initial thoughts on interdependence were surfaced by COL Stephen Runals, U.S. Army Training and Doctrine Command during an interview by author on $17 \mathrm{Feb} 1999$, Ft Monroe, VA.

${ }^{28}$ COL Albert F. Turner, Director, Joint Venture Office, U.S. Army Training and Doctrine Command, interview by author, 18 Feb 1999, Ft Monroe, VA.

${ }^{29}$ LTC Michael Finnigan, USAF, Student, U.S. Army War College, interview by author, 26 Feb 1999, Carlisle Barracks, PA.
} 


\section{BIBLIOGRAPHY}

Addington, Larry H. The Blitkrieg Era and the German General Staff, 1865-1941. New Brunswick: Rutgers University Press, 1971.

Caidin, Martin. The Tigers are Burning. New York: Hawthorn Books, Inc., 1974.

Carell, Paul. Hitler Moves East 1941-1943. Boston: Little, Brown and Co., 1964.

Carell, Paul. Scorched Earth. Boston: Little, Brown and Co., 1970.

Clark, Alan. Barbarossa. New York: Quill Press, 1965.

Cooper, Matthew. The German Army. Lanham, MD: Scarborough House, 1990.

Craig, Gordon A. The Politics of the Prussian Army. London: Oxford University Press, 1955.

Department of Defense. Concept for Future Joint Operations, Expanding Joint Vision 2010. Washington, D.C.: U.S. Department of Defense, May 1997.

Department of the Army. Comparative Logistical Systems, U.S. Army Command and General Staff College. RB 54-2. Washington, D.C.: U.S. Department of the Army, May 1961.

Department of Defense. Quadrennial Defense Review. Washington, D.C: U.S. Department of Defense., May 1997.

Department of the Army. Decisive Force: The Army in Theater Operations. Field Manual 100-7. Washington, D.C.: U.S. Department of the Army, May 1995.

Department of the Army. Division Operations. Field Manual 71-100. Washington, D.C.: U.S. Department of the Army, 28 August 1996.

Department of the Army. Force XXI Operations. Training and Doctrine Command Pamphlet 525-5. Washington, D.C.: U.S. Department of the Army, 1 August 1994.

Department of the Army. Future Operational Capability. Training and Doctrine Command Pamphlet 525-66. Washington, D.C.: U.S. Department of the Army, 1 May 1997

Department of the Army. Historical Study: German Defense Tactics Against Russian Breakthroughs. Washington, D.C.: U.S. Department of the Army, October, 1951.

Department of the Army. Knowledge and Speed - The Annual Report of the Army After Next Project to the Chief of Staff. Washington, D.C.: U.S. Department of the Army, July, 1997.

Department of the Army. The Annual Report of the Army After Next Project to the Chief of Staff of the Army. Washington D.C.: U.S. Department of the Army, December 1998.

Department of the Army. Land Combat in the $21^{\text {st }}$ Century. Training and Doctrine Command Pamphlet (unnumbered), TRADOC CDR's Black Book No 4. Washington, D.C.: U.S. Department of the Army, 1996.

Department of the Army. Operations. Field Manual 100-5. Washington, D.C.: U.S. Department of the Army, June 1993.

Department of the Army. Operations, Revised Final Draft. Field Manual 100-5. Washington, D.C.: U.S. Department of the Army, June 1998. 
Department of the Army. German Defense Tactics Against Russian Breakthroughs. Pamphlet No. 20-233. Washington D.C.: U.S. Department of the Army, October, 1951.

Department of the Army. Tactics, Revised Initial Draft. Field Manual 100-40. Washington, D.C.: U.S. Department of the Army, June 1997.

Department of the Army. The Future of American Landpower: Strategic Challenges for the $21^{\text {st }}$ Century Army. Strategic Studies Institute, U.S. Army War College. Washington D.C.: U.S. Department of the Army, 1996.

Department of the Army. U.S. Army War College, 1984 Art of War Symposium, From the Don to the Dnieper: Soviet Offensive Operations, December 1942-August 1943. Transcript of Proceedings, Washington, D.C.: U.S. Department of the Army, 1984.

Department of the Air Force. Air Force Basic Doctrine. Air Force Doctrine Document 1. Washington, D.C.: U.S. Department of the Air Force, September 1997.

Dupuy, T.N. A Genius for War. London: MacDonald and Jane's Press. 1977.

Erickson, Earl F., Stalingrad to Berlin, The German Defeat in the East, Washington D.C.: U.S. Army Center of Military History, 1987.

Hart, B. H. Liddell. The German Generals Talk. New York: Quill Press, 1979.

Jukes, Geoffrey. Kursk: The Clash of Armour. New York: Ballantine Books Inc., 1970.

Lucas, James. War on the Eastern Front. London: Jane's Publishing Co., 1979.

Macksey, Kenneth. Guderian: Creator of the Blitzkrieg. New York: Stein and Day Publishers, 1975.

Manstein, Erich von. Lost Victories. Navato: Presidio Press, 1982.

Mellenthin, F.W. von. Panzer Battles. Oklahoma: University of Oklahoma Press, 1971.

Metz, Steven. "Analyzing Strategic and Operational Risk." Military Review Magazine, November 1991: 78.

Plocher, Hermann. The German Air Force Versus Russia, 1943, Air University: USAF Historical Studies: No. 155, June 1967.

Stahlberg, Alexander. Bounden Duty. London: Brassey's, 1990.

Taylor, Telford, Sword and Swastika. Chicago: Quadrangle Books, 1969.

The Song of Roland. Trans. W.S. Merwin. New York: Random House, 1970. 